Published as Andrew Lynch and Alysia Blackham, 'Reforming Responses to the Challenges of Judicial Incapacity’ (2020) 48(2) Federal Law Review 214-246

https://doi.org/10.1177/0067205X20905963

\title{
Reforming Responses to the Challenges of Judicial Incapacity
}

\author{
Andrew Lynch* and Alysia Blackham**
}

\begin{abstract}
Judicial incapacity, while under-researched, presents unique challenges for supporting and responding to issues of judicial performance. In this paper, we argue for a reconceptualisation of this topic, based on contemporary theories of socially-constructed disability, and principles of anti-discrimination law. While assisting and supporting judicial officers who are attempting to work with a disability or ongoing health issue will always be complex, this reconceptualisation offers heads of jurisdiction, conduct commissions and parliamentarians, who retain the ultimate sanction of removal, the opportunity to craft a surer guide for handling cases of incapacity. This will not only better serve the individual concerned, affording them greater agency and dignity than has traditionally been the case, but also protect the principle of judicial independence.
\end{abstract}

\section{INTRODUCTION}

Judicial incapacity is a problem of growing relevance for the Australian judiciary. In a 2016 survey of 142 Australian judicial officers, 77 per cent of respondents agreed that it would be appropriate for judicial officers to be asked to undergo capacity checks at the request of a Head of Jurisdiction or a relevant body constituted by judges', and only 12 per cent expressed any disagreement. ${ }^{1}$ Judges responding to that survey made a number of pointed comments, emphasising the practical and philosophical difficulties raised by judicial incapacity for judges and their colleagues. For one judge, judicial incapacity was seen as a 'very vexed issue [that] would require extraordinary sensitivity and safeguards'.2 Another noted, 'Although comparatively rare, senile judges present real problems. The existence of a formalised structure would make it easier to deal with'. ${ }^{3}$ For respondents, then, judicial incapacity is a live problem, that demands a better, more structured response than it currently receives.

Despite this very clear signal that judicial incapacity is seen as an area of contemporary challenge to the judiciary, one that raises a particular range of sensitivities and ethical issues, it has received only very limited recognition in the Australian literature. Instead, the focus has often been upon judicial misbehaviour, a term that is capable of very broad application. Despite some earlier assertions to the contrary in Australia, judicial misbehaviour is not limited to actions undertaken in the course of judicial duties nor to conduct off the bench that would result

* $\quad$ Professor, Gilbert + Tobin Centre of Public Law, Faculty of Law, University of New South Wales.

** Associate Professor, Melbourne Law School, University of Melbourne; Discovery Early Career Research Fellow, Australian Research Council.

Gabrielle Appleby et al, 'Contemporary Challenges Facing the Australian Judiciary: An Empirical Interruption’ (2018) 42(2) Melbourne University Law Review (advance).

Ibid.

Ibid. 
in a criminal conviction. ${ }^{4}$ Accordingly, the scope for complaints of judicial misconduct is broad and eludes any attempt at comprehensive prescription in advance. ${ }^{5}$ However, what is clear is that misbehaviour, and the question of whether a judge may be removed from office for failing to satisfy the condition of 'good behaviour' upon which his or her constitutional security of tenure depends, is inherently concerned with questions of professional propriety and ethical conduct. Assessing many allegations of this kind will require recourse to those generally accepted standards of professional behaviour that are viewed as necessary for the maintenance of public confidence in the courts. This is just as true for misconduct that does not warrant the ultimate sanction of removal but might, depending on what arrangements are in place, attract some lesser response, such as referral to an investigatory complaints body, a reprimand or pastoral counselling. To put it simply, a discussion about judicial misbehaviour - of whatever degree of seriousness - is a discussion about judicial ethics.

By contrast, the ethical dimensions of judicial incapacity, often expressly provided for as an alternative constitutional ground for removal, are of a very different order. While misbehaviour arises directly from a breach of judicial ethics, incapacity, lacking an intentional element, does not. ${ }^{6}$ Incapacity may occasionally manifest in behaviour that looks like, and may be initially regarded as, misconduct, ${ }^{7}$ but it is obviously not accurate to simply describe the judge as having acted unethically. On those occasions, the breach of an accepted standard of professional conduct is but a symptom of the real problem; it is not the problem itself. Thus, there is a need for a structured process to respond to incapacity, which acknowledges its particular challenges.

The limited attention given to the topic of judicial incapacity is puzzling for several reasons. First, there have been a number of troubling episodes over the last two decades, some discussed below, in which the difficulty of identifying and responding to judicial incapacity have been starkly apparent.

Second, physical or mental impairment would seem just as, if not more, likely to arise than instances of intentional wrongdoing or misconduct. A well-placed faith in the high professional and ethical integrity of the Australian judiciary means that 'misbehaviour', while never out of the question, must still be a surprising occurrence. Conversely, judicial officers are, at least in terms of physical and mental health, human beings, the same as everyone else.

Third, an increased incidence of poor health or impairment among the judiciary must be a likely consequence of the expansion in number of the modern judiciary. ${ }^{8}$ As a group, the judiciary simply cannot be immune from the physical and mental health issues that are found in the general population. It has been suggested for some time that the heavy workload and stresses

$4 \quad$ Rosemary Laing (ed), Odgers' Australian Senate Practice: As Revised by Harry Evans (Department of the Senate, $14^{\text {th }}$ ed, 2016) 705.

5 This is not to ignore the utility of guides to judicial conduct, but these themselves tend to emphasise that they are not intended to be prescriptive: see Australasian Institute of Judicial Administration, Guide to Judicial Conduct ( $3^{\text {rd }}$ ed, 2017) 1 [1.1]. See further Gabrielle Appleby and Suzanne Le Mire, 'Judicial Conduct: Crafting a System That Enhances Institutional Integrity' (2014) 38(1) Melbourne University Law Review 1, 51-3.

Appleby and Le Mire (n 5) 9.

Ibid 24, 59.

See Commonwealth, Parliamentary Debates, House of Representatives, 5 September 2005, 18 (Duncan Kerr). 
of judicial office exact a particular toll upon those serving on the bench. ${ }^{9}$ But while Australian research confirms that psychological distress, overuse of alcohol and burnout are certainly issues facing the judiciary, it also found that 'lawyers' reporting rates of depression, anxiety, and stress symptoms were more than three times those found for judicial officers' who participated in the study. ${ }^{10}$ This research complements earlier examinations of practising lawyers. A 2007 study found that lawyers in Australia are more likely to suffer from moderate to severe depression than any other profession. ${ }^{11}$ Additionally, 'legal professionals were also more likely to use alcohol and other drugs to reduce or manage feelings of sadness and depression when compared with the other professional groups' ${ }^{12}$ A national survey of Australian legal practitioners also confirmed 'a remarkably high level of self-reported stress and negative emotional states' ${ }^{13}$

The fact that the judicial study posits that the legal profession is far more at risk than the judiciary is not exactly a source of comfort. Although the authors suggest three reasons why judges report less severe mental health issues than the profession, ${ }^{14}$ it is hard to view the two groups as entirely distinct given that one is drawn from the other; and the problems are ones that might be expected to have some potential for transference. Additionally, the more socially isolated nature of judicial work and the particular responsibility that it carries, may present altogether new causes of stress. Indeed, in Appleby and others' survey of Australian judges, some noted that high workloads and resulting stress were affecting judges' physical and mental health. ${ }^{15}$ Workload is an issue that affects growing numbers of the judiciary, across all levels of seniority and age bands.

Fourth, in the context of emerging calls to consider the position of judges as individuals, with their own employment rights and workplace needs, ${ }^{16}$ and growing scrutiny of potential

$9 \quad$ See Susan Denham, 'The Diamond in a Democracy: An Independent, Accountable Judiciary' (2001) 5(1) Judicial Review 31, 38; Michael Kirby, 'Judicial Stress' (1995) 13(2) Australian Bar Review 101, $104-$ 13 ('Judicial Stress').

10 Carly Schrever, Carol Hulbert and Tania Sourdin, 'The Psychological Impact of Judicial Work: Australia's First Empirical Research Measuring Judicial Stress and Wellbeing' (2019) 28(3) Journal of Judicial Administration 141, 163.

11 Beyond Blue, ‘Annual Professions Survey' (Research Summary, April 2007) 2-3. $<$ http://www.judicialcollege.vic.edu.au/sites/default/files/2007\%20-\%20Beyond $\% 20$ Blue $\% 20-\% 20$ Annu al\%20Professions\%20Survey.pdf $>$. Encouragingly, four years later, lawyers 'reported the highest levels of mental health training' of the professions surveyed and were 'the professional group most likely to have completed the Beyond Blue National Workplace Program training'. However, in 2011 'compared to other professions, lawyers felt their organisations were less likely to actively help an individual seek treatment': Beyond Blue and Beaton Consulting, '2011 Annual Business and Professions Survey' (Research Summary, May 2011) 3

$<$ https://das.bluestaronline.com.au/api/BEYONDBLUE/document?token=BL/0903>.

$12 \quad$ Beyond Blue (n 11) 3.

13 Janet Chan, Suzanne Poynton and Jasmine Bruce, 'Lawyering Stress and Work Culture: An Australian Study’ (2014) 37(3) University of New South Wales Law Journal 1062, 1063.

14 Being the differences in the work, the aptitude shown by those selected for judicial office and the mature age of judicial appointment: see Schrever, Hulbert and Sourdin ( $\mathrm{n} 10)$.

15 Appleby et al (n 1).

16 Alysia Blackham, 'Reconceiving Judicial Office through a Labour Law Lens' (2019) 47(2) Federal Law Review (forthcoming). 
discrimination in court practices (especially on the basis of age ${ }^{17}$ and gender ${ }^{18}$ ), it is timely to review how courts are managing cases of incapacity, and the extent to which this accords with changing societal norms towards disability and discrimination. This is important for both judicial retention and recruitment, ${ }^{19}$ and to ensure the integrity of court practices.

Yet, despite the potential significance of judicial incapacity, in the third edition of the magisterial work by former Queensland Court of Appeal judge James Thomas, Judicial Ethics in Australia, this topic receives just three paragraphs of dedicated attention in its own right. ${ }^{20}$ This brevity stems from a reluctance, hardly exclusive to that book's author, to see judicial incapacity as requiring some more systematic and specific set of responses. Attempts to semiformalise judicial complaints at the Commonwealth and state level have tended to display a similar reticence about the desirability of mechanisms tailored for the handling of allegations or fears of judicial incapacity. Instead, the dominant focus of those legislative reforms has been upon the development of processes for the investigation and resolution of allegations of misbehaviour. This is despite the fact that there is greater uncertainty over standards, rights and procedural fairness in cases of incapacity.

The aim of this paper is to redress this imbalance by highlighting that judicial incapacity raises specific challenges and issues that require systematic responses. We argue that incapacity must be seen in its social and institutional context: discussions of incapacity cannot just focus on the individual judge. Using this social model, we argue for a more principled approach to determining the existence of judicial incapacity that justifies the removal of an individual from the bench. This would refine efforts to precede the constitutional mechanism of parliamentary removal with some more nuanced and finely calibrated process, while also ensuring that a more ethical and less ad hoc or discretionary response is made to cases of judicial incapacity. Achieving greater clarity around the mutual obligations that arise in respect of judicial impairment would also better serve the underlying constitutional imperative of protecting the independence of judges not only from interference by the other arms of government but also from their own colleagues.

We commence in Part II with a discussion of judicial tenure and removal, and the role that incapacity might play in the removal of judges. In Part III we consider the meaning and differences between 'misbehaviour' and 'incapacity', and argue that these differences mean that dealing with incapacity requires a different, more nuanced process than that available for dealing with misbehaviour. In Part IV we use a discrimination law lens and social model of disability to develop and inform of our discussion of incapacity; in Part V we apply these

17 Alysia Blackham, ‘Judges and Retirement Ages' (2016) 39(3) Melbourne University Law Review 738; Alysia Blackham, 'Judicial Retirement Ages in the UK: Legitimate Aims and Proportionate Means?' [2017] (April) Public Law 196; Brian Opeskin, 'The High Cost of Judges: Reconsidering Judicial Pensions and Retirement in an Ageing Population' (2011) 39(1) Federal Law Review 33; Brian Opeskin, 'Models of Judicial Tenure: Reconsidering Life Limits, Age Limits and Term Limits for Judges' (2015) 35(4) Oxford Journal of Legal Studies 627 ('Models of Judicial Tenure').

18 See, eg, Rachel Davis and George Williams, 'Reform of the Judicial Appointments Process: Gender and the Bench of the High Court of Australia' (2003) 27(3) Melbourne University Law Review 819; Graham Gee and Erika Rackley (eds), Debating Judicial Appointments in an Age of Diversity (Routledge, 2017); Elizabeth Handsley and Andrew Lynch, 'Facing Up to Diversity? Transparency and the Reform of Commonwealth Judicial Appointments 2008-13' (2015) 37(2) Sydney Law Review 187.

19 Brian Opeskin, 'The Supply of Judicial Labour: Optimising a Scarce Resource in Australia' (2017) 7(4) Oñati Socio-Legal Series 847.

20 James Thomas, Judicial Ethics in Australia (LexisNexis, $3^{\text {rd }}$ ed, 2009) 55-6. 
lessons to critique existing structures for dealing with incapacity. Finally, in Part VI we offer suggestions and recommendations for designing a process to address judicial incapacity.

\section{JUDICIAL TENURE AND REMOVAL}

Any system of judicial tenure and removal must be aimed at securing judicial independence. A strongly independent judiciary is the cornerstone of an effective separation of powers, which in turn enhances the polity's governance in accordance with the rule of law. ${ }^{21}$ Judicial independence involves both independence from governmental or executive interference and a degree of independence within the judiciary from judicial colleagues. ${ }^{22}$ In this regard, the signature moment in the development of the English Constitution was the protection conferred upon judicial tenure by the Act of Settlement 1701 (UK) ('Act of Settlement'), a corrective to the vulnerability of the courts under the Stuart Kings in the preceding century that had been possible by judges' commissions being expressed in the letters patent as 'at the King's pleasure'. ${ }^{23}$

With judicial independence, however, comes the challenge of accountability. Procedures for judicial removal typically seek to achieve a balance between judicial independence and judicial accountability. In the Act of Settlement, this was achieved by guaranteeing the holding of judicial office during 'good behaviour', but allowing judicial removal upon the address of both houses of Parliament. ${ }^{24}$ The Act of Settlement did not, at least initially, achieve a simple and complete assumption by parliament of the power to remove judges, but rather conditioned the executive's power of removal upon a breach of 'good behaviour' while adding a parliamentary mechanism for removal that was absent any constraint as to grounds. ${ }^{25}$ However, the independent executive's role in the removal of judges was in fact the product of both further legislative enactment and desuetude. Only by a statute of 1760 did judicial offices cease to be vacated upon the death of the sovereign, while the writ of scire facias by which the executive might remove a judge for breach of 'good behaviour' simply fell into disuse. As a matter of constitutional law, the path of parliamentary removal alone remains open as the means of judicial accountability. ${ }^{26}$

21 Elizabeth Handsley, 'Public Confidence in the Judiciary: A Red Herring for the Separation of Judicial Power’ (1998) 20(2) Sydney Law Review 183, 187.

22 The latter sense in which judges should be independent has tended to receive less attention than incursions from the other arms of government, but on this see Murray Gleeson, 'The Right to an Independent Judiciary' (2006) 16 Commonwealth Judicial Journal 6, 12; J D Heydon, 'Threats to Judicial Independence: The Enemy Within' (2013) 129(2) Law Quarterly Review 205. J W F Allison, The English Historical Constitution: Continuity, Change and European Effects (Cambridge University Press, 2007) 81.

24 The modern equivalent of the relevant provision for judges on the United Kingdom's High Court and Court of Appeal is found in the Senior Courts Act 1981 (UK) s 11(3) and for judges on the Supreme Court in the Constitutional Reform Act 2005 (UK) s 33. The subsequent curtailment of judicial tenure for life in England (and many of other jurisdictions including Australia) is distinct from discussion of removal from office.

25 Shimon Shetreet and Sophie Turenne, Judges on Trial: The Independence and Accountability of the English Judiciary (Cambridge University Press, $2^{\text {nd }}$ ed, 2013) 22-9.

26 It should be noted that in the United Kingdom, protection of judicial independence from the Executive is limited to the senior judiciary at the level of the High Court of Justice and above. Since 2005, processes have existed by which the executive office of the Lord Chancellor may, with the agreement of the Lord Chief Justice, the head of the judiciary, terminate or suspend lower level judicial commissions: Constitutional Reform Act 2005 (UK) ss 108-21 and regulations made pursuant to s 115. Judicial officers at the lower court levels have been removed from the bench in this way in more recent times: see Kate Malleson, 'Appointment, Discipline and Removal of Judges: Fundamental Reforms in the United 
The fact that the legislature acquired the exclusive power of judicial removal through stages, rather than a single constitutional moment, is of assistance when considering the different ways in which that power finds expression in the constitutions within the Australian federation. Showing most clearly the influence of the relevant provision in the Act of Settlement as laying down 'two channels by which a judge's tenure might be brought to an end', ${ }^{27}$ the Constitutions of the states of Western Australia and South Australia both contain provisions that sustain the commissions of judges 'during their good behaviour'. ${ }^{28}$ In both Constitutions, a separate section provides that a judge may be removed by the Crown on the address of both Houses. ${ }^{29}$ It cannot be that this drafting arrangement, which has a clear parallel with the national constitutions of Canada and the United States ${ }^{30}$ preserves the long lost executive power to seek removal of a judge for misbehaviour via a writ of scire facias. Instead, it merely reflects that history. By contrast, the earlier bifurcation of powers with respect to removal is not at all discernible in respect of the Tasmanian judiciary, where the equivalent provision merely states that it is unlawful for the Governor to remove any judge of the Supreme Court unless he or she does so after an address by both Houses of Parliament. ${ }^{31}$ What these three States have in common is a section in their constitutions that empowers the legislature to remove judicial officers that is expressed free of any condition or ground for doing so. ${ }^{32}$

However, even in the absence of express grounds upon which a parliamentary address for judicial removal may be made, the legislature's power is not, as a matter of constitutional convention, simply at large. That view was confirmed by a committee established by the Canadian Judicial Council to inquire into whether a trial judge in Ontario could be removed on the ground of incapacity, despite the Canadian Constitution's simple prescription of judicial tenure as 'during good behaviour'. ${ }^{33}$ In finding that a judge might indeed be removed due to incapacity despite no express reference to that ground, a majority of the committee sought simultaneously to justify and contain their recognition of a broader power of removal:

[S]ection 99(1) of the Constitution Act, 1867, establishes a tenure for superior court judges 'during good behaviour'. It also authorizes Parliament to conduct proceedings for the removal of superior court judges without specifying the possible grounds for removal. Constitutionally, those grounds [of removal] must be determined with the guidance of common law, parliamentary practice and tradition, and whatever additional considerations may be relevant to maintain and enhance the principle of judicial independence in Canada today. ${ }^{34}$

Kingdom' in H P Lee (ed) Judiciaries in Comparative Perspective (Cambridge University Press, 2011) 117, 128-9; Shetreet and Turenne ( n 25) 286-7. Opeskin, 'Models of Judicial Tenure' (n 17) 637. Constitution Act 1934 (SA) s 74; Constitution Act 1889 (WA) s 54. The drafters of the West Australian provision additionally felt it prudent to expressly incorporate the effect of the 1760 Act by providing that judicial tenure continued 'notwithstanding the demise of Her Majesty (whom may God long preserve)'. Constitution Act 1934 (SA) s 75; Constitution Act 1889 (WA) s 55. Constitution Act 1867 (Imp) 30 \& 31 Vict, c 3, s 99(1); United States Constitution art III § 1 of which provides that federal judges enjoy tenure during their 'good behaviour', while their removal is available only to Congress through the impeachment process of art II $\S 4$.

$31 \quad$ Supreme Court (Judges' Independence) Act 1857 (Tas) s 1.

32 It is generally agreed in academic writing on the Act of Settlement itself and equivalent provisions that the stipulation of 'good behaviour' as a condition of judicial tenure in and of itself (as in the Western Australian and South Australian Constitutions) does not restrict the parliamentary power of removal to circumstances meeting that ground: see Decision of the Inquiry Committee: Under Subsections 63(2) and 63(3) of the Judges Act in Relation to Mr Justice F L Gratton of the Ontario Court of Justice (General Division) (Inquiry Committee Decision, February 1994) 30-1 ('Gratton Inquiry Committee'). 
One judicial member of the five-person committee preferred, as did the single judge of the Federal Court of Canada who subsequently heard an application for judicial review of the committee's decision, ${ }^{35}$ to see an inability to perform the duties of judicial office as a failure to comply with the 'good behaviour' requirement. ${ }^{36}$ But this opinion did not deny the determinative guidance of the common law and past practices consistent with the contemporary significance of the principle of judicial independence. Crucially, the committee was unanimous that the grounds upon which Parliament might seek judicial removal were not 'unrestricted' ${ }^{37}$ Its members went on to opine that 'practically speaking, it is difficult to conceive of any possible grounds upon which Parliament could remove a superior court judge other than misbehaviour or infirmity'. ${ }^{38}$

It is also a matter of clear international consensus that judicial independence is protected by condoning the removal of judges only on these two grounds. Article 18 of the United Nations 'Basic Principles on the Independence of the Judiciary 1985' says that judges 'shall be subject to removal only for reasons of incapacity or behaviour that renders them unfit to discharge their duties' ${ }^{39}$ In 2003, the Commonwealth Heads of Government adopted the so-called 'Latimer House Principles on the Accountability of and the Relationship between the Three Branches of Government' ('Latimer House Principles'). Principle IV addresses Independence of the Judiciary and states that 'Judges should be subject to suspension or removal only for reasons of incapacity or misbehaviour that clearly renders them unfit to discharge their duties'. ${ }^{40}$ The 'Mount Scopus International Standards of Judicial Independence', a consolidation and revision of many preceding standards, state that a judge shall not be subject to removal unless by 'physical and mental incapacity he has shown himself manifestly unfit to hold the position of judge' before also adopting the standard of the incapacity rendering 'the judge unfit to discharge their duties'. ${ }^{41}$

Thus, even where the legislature's power is expressed as being free of any condition or ground for judicial removal, convention and international consensus will likely limit this power to the grounds of misbehaviour and incapacity. In addition to the relevance of the constraining factors identified by the Canadian inquiry committee, an unbounded power appears incompatible with the High Court of Australia's jurisprudence about the limits derived from the Commonwealth Constitution upon state legislatures so as to preserve the institutional integrity of state courts

\footnotetext{
35 Gratton v Canada (Judicial Council) (1994) 115 DLR $\left(4^{\text {th }}\right) 81,98$.

$36 \quad$ Gratton Inquiry Committee (n 32) 31, 38.

37 Ibid 31.

$38 \quad$ Ibid

39 'Basic Principles on the Independence of the Judiciary: Adopted by the Seventh United Nations Congress on the Prevention of Crime and the Treatment of Offenders held at Milan from 26 August to September 1985 and endorsed by General Assembly Resolutions 40/32 of 29 November 1985 and 40/146 of 13 December 1985', United Nations Human Rights Office of the High Commissioner (Web Page, 2019) [18] $<$ https://www.ohchr.org/EN/ProfessionalInterest/Pages/IndependenceJudiciary.aspx $>$. Commonwealth Heads of Government, Latimer House Principles on the Accountability of and the Relationship between the Three Branches of Government (Guidelines, November 2003) 11 [IV].

41 'Mount Scopus Standards of Judicial Independence 2008' cl 5.5: Shimon Shetreet and Christopher Forsyth (eds), The Culture of Judicial Independence: Conceptual Foundations and Practical Challenges (Martinus Nijhoff Publishers, 2012) app I, 507-8. Similar clauses to those quoted in the main text are to be found across the larger suite of international standards of judicial independence: see the appendices in Part VII of Shimon Shetreet and Christopher Forsyth (eds), The Culture of Judicial Independence: Conceptual Foundations and Practical Challenges (Martinus Nijhoff Publishers, 2012).
} 
as receptacles of federal judicial power. ${ }^{42}$ Thus, notions of incapacity and misbehaviour are still accepted as those which alone govern the power of judicial removal, even in those jurisdictions where these do not expressly appear as grounds for the legislature to act.

Pursuant to section 72 of the Commonwealth Constitution, these two grounds for removal are explicitly imposed on the federal legislature, which provides that federal judges 'shall not be removed except by the Governor-General in Council, on an address from both Houses of Parliament in the same session, praying for such removal on the ground of proved misbehaviour or incapacity'. ${ }^{43}$ The states of New South Wales, ${ }^{44}$ Victoria ${ }^{45}$ and Queensland, ${ }^{46}$ as well as the Australian Capital Territory ${ }^{47}$ and the Northern Territory, ${ }^{48}$ all now provide for parliamentary removal on these same two alternate grounds. Thus, across the Australian jurisdictions, attempting to delineate 'misbehaviour' and 'incapacity', and their possible limits, is an important task.

\section{MiSBEHAVIOUR AND INCAPACITY}

To accept that the parliamentary power of judicial removal is limited, whether formally or as a matter of convention, to the two grounds of misbehaviour and incapacity is simply to acknowledge the broad parameters of that power. The more challenging question is to determine just how constraining either term is, as a condition upon its exercise.

Australia has come to develop an especially generous conception of 'misbehaviour' (or, alternatively, a breach of 'good behaviour'). In both England and the United States, removal of a judicial officer by the legislature has only occurred when the conduct complained of was at least capable of being viewed as criminal. In England only one judge has been removed from office upon a motion by both houses of Parliament, and that was in 1830 after he was found guilty of embezzling court fees. ${ }^{49}$ Impeachment proceedings in the United States against federal judges have been more frequent but have traditionally been contingent upon a criminal charge having been laid (though not necessarily upon a conviction resulting). ${ }^{50}$ In an assessment that seems apt for both jurisdictions, Professor Kate Malleson has surmised that in England the 'definition of misbehaviour as limited to such criminal behaviour is now a strong convention and any attempt to institute proceedings for anything less serious would be very unlikely to succeed'. ${ }^{51}$

In Australia a more academic approach to the definitional question has taken place. Although a fairly narrow understanding of 'misbehaviour' was initially advanced as the controversy over

Essentially, what is known as the 'Kable doctrine' after Kable v Director of Public Prosecutions for New South Wales (1996) 189 CLR 51.

43 This provision is replicated in the Federal Court of Australia Act 1976 (Cth) s 6; Family Law Act 1975

(Cth) s 22; and Federal Circuit Court of Australia Act 1999 (Cth) sch 1 s 9.

$44 \quad$ Constitution Act 1902 (NSW) s 53.

$45 \quad$ Constitution Act 1975 (Vic) ss 77(1), 87AAB(1).

46 Constitution of Queensland 2001 (Qld) s 61(2).

$47 \quad$ Judicial Commissions Act 1994 (ACT) s 5(1).

$48 \quad$ Supreme Court Act 1979 (NT) s 40(1).

$49 \quad$ Malleson (n 26) 127.

50 Mark Tushnet, 'Judicial Selection, Removal and Discipline in the United States' in H P Lee (ed), Judiciaries in Comparative Perspective (Cambridge University Press, 2011) 134. Tushnet said that impeachment has occurred 'only when a federal judge has been charged with criminal misconduct', but no charge was laid before the impeachment of Judge Thomas Porteous who was removed from office in December 2010: at 141. 
the allegations against High Court judge Lionel Murphy unfolded in the early $1980 \mathrm{~s},{ }^{52}$ this was swiftly overtaken by apparent consensus that the term 'extends to any behaviour indicating unfitness for judicial office'. ${ }^{53}$ This is not confined to behaviour that may amount to criminal activity, nor to conduct occurring in the Court or relating purely to the fulfilment of judicial duties. ${ }^{54}$ This larger sense of 'misbehaviour' was accepted by the counsel to the Senate Select Committee on the Conduct of a Judge and all three members of the later Parliamentary Commission of Inquiry that were established in succession to investigate a myriad of claims against Murphy. ${ }^{55}$ Murphy's death in 1986 ensured that the understanding adopted by either body was never put to the test of parliamentary approval. ${ }^{56}$ However, confirmation of this broad conception was effectively offered just a few years later, upon the occasion of the only successful removal of an Australian judge from office. In 1989, when the Legislative Assembly in the State of Queensland passed a motion to address the Governor to remove Justice Angelo Vasta from the Supreme Court, the Queensland Constitution provided simply that judges were to hold office 'during their good behaviour'. Evans and Laing have said that despite the fact that the relevant actors 'were all careful not to say that misbehaviour was the ground of removal', Vasta's case nevertheless offers 'significant precedent for a consideration of conduct which may be regarded as constituting misbehaviour', under a broad understanding not limited to actions undertaken in the course of judicial duties or supplying the basis for a criminal conviction. ${ }^{57}$ It has also been argued by the Law Council of Australia that even conduct prior to the individual's judicial appointment may provide the basis for removal on the ground of 'misbehaviour'. ${ }^{58}$

The debate around just how expansively 'misbehaviour' should be understood treads a fine line between the need to preserve public confidence in the courts and not exposing the judiciary to political interference. It is a discussion that, given the unpredictability of human behaviour and the inevitability of a range of contextual factors, cannot in the abstract determine a definitive catalogue of conduct that will fail to meet the standard of 'good behaviour'. ${ }^{59}$ That said, it is not uncommon for jurisdictions to have publicly available guides to judicial conduct that, despite the presence of disclaimers as to their relevance to disciplinary purposes, inevitably inform and shape standards of behaviour against which complaints are measured in practice. ${ }^{60}$

In contrast to the detailed consideration in Australia over the meaning of 'misbehaviour' during and since the Murphy affair, Campbell and Lee have said that judicial incapacity 'has not given

Evidence to Senate Select Committee on the Conduct of a Judge, Parliament of Australia, Canberra, 24 February 1984 (Gavan Griffith).

53 Laing (n 4) 680. See also Enid Campbell and H P Lee, The Australian Judiciary (Cambridge University Press, $2^{\text {nd }}$ ed, 2013), 122-4; Thomas (n 20) 15-20. Kevin O'Connor, 'Judicial Conduct out of Court' (2006) 8(1) Judicial Review 81.

Laing (n 4); Campbell and Lee (n 53).

For a recent precise account of each development in the 'Murphy Affair', see Stephen Walmsley, The Trials of Justice Murphy (LexisNexis, 2016).

Laing (n 4) 707-8: 'The Commission reported that the following behaviour by the judge warranted his removal from office: (a) giving false evidence at a defamation hearing; (b) making and maintaining allegations that the Chief Justice, the Attorney-General and the inquiry commissioner had conspired to injure him; (c) making a false statement to an accountant who prepared income tax returns; (d) arranging sham transactions to gain income tax advantages; (e) making false claims for taxation deductions'. Campbell and Lee (n 53) 123-4; Thomas (n 20) 19-20.

Shetreet and Turenne (n 25) 293.

Appleby and Le Mire (n 5) 53-4. 
rise to controversy', which may be somewhat overstating it. ${ }^{61}$ While true as a political fact, this statement also appears to suggest a definitional assumption that the identification of physical and mental incapacity is a straightforward matter, unlike the highly complex and situationspecific question of whether a judge has conducted himself or herself with probity.

While the potential range and variation among cases of misconduct is obvious, 'incapacity' is equally attended by its own difficulties and uncertainties. While 'incapacity' is a term familiar to lawyers - featuring most obviously in respect of an individual's capacity to assent in areas governed by the law of contract, tort and succession - the meaning of the term is quite different, and more complex, in relation to the specific matter of the performance of judicial duties. Thus, it is doubtful how much guidance can be obtained from discussions in other areas of law. Accordingly, the identification of judicial incapacity, let alone determining the best and most appropriate response to it, may present real challenges.

Further, it is important to acknowledge the potential overlap between incapacity and misbehaviour: as noted above, incapacity may occasionally manifest in behaviour that looks like, and may be initially regarded as, misconduct. ${ }^{62}$ At first, it may be difficult to discern whether the case is one of misbehaviour or incapacity. Unexcused absence and neglect of judicial duties have long been recognised as instances of misbehaviour, ${ }^{63}$ but these and other failings may ultimately be explained as the consequence of a medical condition from which the judge is suffering. In recent examples, a judge's sleeping during a criminal trial was put into medical perspective by a later diagnosis of severe obstructive sleep apnoea; ${ }^{64}$ and a magistrate's bullying manner and perceived unfairness to defendants was attributed to her suffering from depression. ${ }^{65}$ While the tendency for some forms of incapacity to manifest as misconduct has implications for the design of a process for managing incapacity, there is an obvious distinction between intentional dereliction and an involuntary inability to perform. On those occasions, the breach of an accepted standard of professional conduct is but a symptom of the real problem; it is not the problem itself.

Thus, there is a need for a structured process to respond to incapacity, which acknowledges its particular challenges and differences to misbehaviour, yet also recognises its potential overlap with misbehaviour. There has been minimal discussion of how this might be achieved in public law scholarship. To address this gap, in the next section we use the lens of discrimination law to offer new insights into how a process to respond to judicial incapacity might be structured.

61 Campbell and Lee (n 53) 122. The authors go on to discuss the affair of Justice Vince Bruce, considered later in this paper, as well as briefly noting later attempts to remove two New South Wales magistrates which involved claims of incapacity. Appleby and Le Mire (n 5) 24, 59.

63 Shetreet and Turenne (n 25) 285-6.

64 In Cesan v The Queen (2008) 236 CLR 358, the High Court upheld an appeal against conviction on the basis that a miscarriage of justice was 'constituted by the judge's substantial failure to maintain the necessary supervision and control of the trial ... his conduct created a distraction during the trial process' and of the jury in particular: at 388 (French CJ).

65 Carolyn Simpson, D H Lloyd and K Moroney, Report of an Inquiry by a Conduct Division of the Judicial Commission of NSW in Relation to Magistrate Jennifer Betts (Report, 21 April 2011) ('Conduct

Division'). In the same vein as the Betts case, New South Wales Magistrate Dominique Burns has referred to mental health issues arising from workload pressures in responding to allegations of misconduct that she improperly detained defendants who appeared in court, denied procedural fairness, and encouraged police prosecutors to lay further charges: see Georgina Mitchell, "Did She Make Mistakes? Yes": Hearing Adjourned to Consider Magistrate's Fate', Sydney Morning Herald (online, 29 November 2018) < https://www.smh.com.au/national/nsw/did-she-make-mistakes-yes-hearing-adjournedto-consider-magistrate-s-fate-20181128-p50iwe.html>. 
The limited academic and judicial consideration of 'incapacity' in the context of judicial removal may be overcome by looking to some aspects of discrimination law, particularly with respect to disability.

In conformity with Australia's international obligations under the 2008 Convention on the Rights of Persons with Disabilities ('the CRPD') and earlier conventions to which it is a signatory, the federal Disability Discrimination Act 1992 (Cth) ('the DDA') makes it unlawful for an employer to discriminate against an employee on the ground of their disability. ${ }^{66}$ That discrimination may be in the working conditions afforded to the employee, the denial of opportunities or benefits associated with their employment or by subjecting the employee to any other detriment. Discrimination, whether direct or indirect, includes the failure to make 'reasonable adjustments' which has, or is likely to have, the effect of treating the person with the disability less favourably. ${ }^{67}$ Similar provisions are in place at the state and territory level.

Karpin and O'Connell have described the $D D A$ as adopting a 'social model' of disability, which emphasises responsibility at an organisational and social level for addressing discrimination. ${ }^{68}$ This may be contrasted with the medical model of disability, which focuses on individual treatment to cure or adapt behaviour. ${ }^{69}$ The social model instead focuses on how individual bodies and societal structures interact to produce disability: ${ }^{70}$ disability is a product of both biology and sociology. ${ }^{71}$ Thus, the social model distinguishes between disability (which relates to social exclusion, and is structural and public) and impairment (which relates to physical limitation, and is individual and private). ${ }^{72}$ Adopting a social model emphasises a collective moral responsibility for addressing barriers for those with a disability, shifting the 'blame' away from individuals themselves. ${ }^{73}$ While the $D D A$ might emphasise the social model of disability, this approach is arguably much more explicit in the CRPD, Article 1 of which states: 'Persons with disabilities include those who have long-term physical, mental, intellectual or sensory impairments which in interaction with various barriers may hinder their full and effective participation in society on an equal basis with others'. Unlike the DDA, the CRPD does not define 'disability' by focussing only upon the individual and his or her impairment.

Later scholars have embraced an "eclectic "model"" of disability, which moves beyond the social model to embrace the diversity, complexity, plurality and multiplicity of disability. ${ }^{74}$ For

66 Disability Discrimination Act 1992 (Cth) s 15(2) (' $D D A$ '). Similar provisions are also contained in state statutes.

$67 \quad$ Ibid ss 5(2), 6(2).

68 Isabel Karpin and Karen O'Connell, 'Stigmatising the "Normal”: The Legal Regulation of Behaviour as a Disability' (2015) 38(4) University of New South Wales Law Journal 1461, 1476. Anna Lawson, 'People with Psychosocial Impairments or Conditions, Reasonable Accommodation and the Convention on the Rights of Persons with Disabilities' (2008) 26(2) Law in Context 62, 68. See also Paul Harpur, 'Sexism and Racism, Why Not Ableism? Calling for a Cultural Shift in the Approach to Disability Discrimination’ (2009) 34(3) Alternative Law Journal 163, 165. Tom Shakespeare, 'The Social Model of Disability' in Lennard J Davis (ed), The Disability Studies Reader (Routledge, $2^{\text {nd }}$ ed, 2006) 197.

71 Susan Gabel and Susan Peters, 'Presage of a Paradigm Shift? Beyond the Social Model of Disability toward Resistance Theories of Disability' (2004) 19(6) Disability \& Society 585, 597. Shakespeare (n 70). See further Tania Burchardt, 'Capabilities and Disability: The Capabilities Framework and the Social Model of Disability’ (2004) 19(7) Disability \& Society 735, 736.

73 Shakespeare (n 70); Burchardt (n 72) 736.

$74 \quad$ Gabel and Peters (n 71) 588. 
Gabel and Peters, this is best encapsulated in a 'resistance' model of disability, which recognises individual agency and focuses on resistance at both individual and collective levels. ${ }^{75}$ Even if we move to a more nuanced idea of disability, which accommodates individual agency and complexity, there is still a need to focus on social structures and struggles that constitute 'disability'. Thus, contemporary disability literature directs attention to the systems that create disability, and the barriers and structures that need to be dismantled to promote inclusion and participation of those with a disability.

Drawing on these models and legislative provisions, we can draw four key lessons which may inform our discussion of processes to manage judicial incapacity: first, on the relationship between 'disability' or impairment and 'incapacity'; second, on the use of 'reasonable adjustments'; third, on 'unjustifiable hardship' that might be imposed on an employer; and, fourth, on the 'inherent requirements' of a position. As the posing of those questions itself demonstrates, resort to the conceptual space of disability law provides us with a vocabulary that has been strikingly absent from the discussion of judicial 'incapacity'.

\section{A Disability and Incapacity}

Under s $4(1)$ of the $D D A$, 'disability' is defined as:

(a) total or partial loss of the person's bodily or mental functions; or

(b) total or partial loss of a part of the body; or

(c) the presence in the body of organisms causing disease or illness; or

(d) the presence in the body of organisms capable of causing disease or illness; or

(e) the malfunction, malformation or disfigurement of a part of the person's body; or

(f) a disorder or malfunction that results in the person learning differently from a person without the disorder or malfunction; or

(g) a disorder, illness or disease that affects a person's thought processes, perception of reality, emotions or judgment or that results in disturbed behaviour;

and includes a disability that:

(h) presently exists; or

(i) previously existed but no longer exists; or

(j) may exist in the future (including because of a genetic predisposition to that disability); or

(k) is imputed to a person.

The section also provides that, to avoid doubt, disability 'includes behaviour that is a symptom or manifestation of the disability'. Thus, at a preliminary level in a judicial context, disability would include any misbehaviour or conduct that arose as a symptom of a disability. As noted in the preceding section of this article, the $D D A$ definition does not include the sociological causes of disability; this is left to the general structure and content of the legislation.

While the definition of disability that appears in section 4(1) of the $D D A$ is broad and wideranging, ${ }^{76}$ this does not mean that a judge with a disability or impairment automatically falls within the notion of 'incapacity'. A judge who experiences mild depression likely has 'a

Ibid 594.

However, the notion of a disability has been critiqued by Karpin and O'Connell, who question the dichotomy between disability and 'normalcy', arguing instead that the line between the two is blurred: Karpin and O'Connell (n 68). Indeed, what is 'disabled' or 'normal' is socially and historically constructed and contingent, and inherently unstable: at 1483. 
disorder, illness or disease that affects a person's thought processes, perception of reality, emotions or judgment'. However, so long as that condition does not affect their work, there can be no argument that the judge should be removed on the grounds of incapacity. (Indeed, given the prevalence of mental health issues in the legal profession, such an embracive definition of 'incapacity' could exclude many worthy candidates from judicial office.)

Essentially, while having a disability or impairment might be a starting point for considering judicial incapacity, it is not conclusive of the question. Seen through a discrimination law lens, 'incapacity' is made out where a judge has an impairment and, after all reasonable adjustments have been made to help them fulfil their judicial role, they are still unable to fulfil the inherent requirements of their office. This approach is consistent with the guidelines to the Commonwealth's 'Latimer House Principles', which justify removal only when the incapacity 'clearly renders them unfit to discharge their duties' ${ }^{77}$ As Jan van Zyl Smit has emphasised, 'This formulation indicates that mental or physical incapacity should only be grounds for removal when the judge is effectively prevented from performing his or her functions'. ${ }^{78}$ Thus, 'incapacity' cannot be considered in isolation from the notions of 'reasonable adjustments' and 'inherent requirements', which are discussed in the sections that follow.

\section{B Reasonable Adjustments}

Under section 4(1) of the $D D A$, reasonable adjustments are simply defined as 'an adjustment to be made by a person ... unless making the adjustment would impose an unjustifiable hardship on the person'. The international Convention provides a more expansive and illuminating definition of the same idea, when it defines 'reasonable accommodation' as meaning:

necessary and appropriate modification and adjustments not imposing a disproportionate or undue burden, where needed in a particular case, to ensure to persons with disabilities the enjoyment or exercise on an equal basis with others of all human rights and fundamental freedoms. $^{79}$

Reasonable adjustments could include, for example, the provision of relevant technology (such as computer screen readers for visual impairments, hearing loops, or particular computer or office equipment); adapting premises (including through the installation of ramps or elevators, or moving of furniture); providing additional support, such as an aide; and/or changing job structures, to enable part-time or flexible work, or to give time off for medical appointments. ${ }^{80}$

Reasonable adjustments or reasonable accommodations are key to the social model of disability: they reflect the social and organisational obligation to address discrimination. A

77 Commonwealth Heads of Government (n 40).

78 Jan van Zyl Smit, The Appointment, Tenure and Removal of Judges under Commonwealth Principles: A Compendium and Analysis of Best Practice (Research Report, May 2015) 82 (emphasis added).

79 Convention on the Rights of Persons with Disabilities, opened for signature 13 December 2006, 2518 UNTS 283 (entered into force 3 May 2008) art 2 ('CRPD').

80 Note, however, that there is a general assumption that equipment for personal use - such as glasses, hearing aids, medication or a wheelchair - does not fall within the scope of 'reasonable adjustments': Australian Human Rights Commission, 'Resource Paper: Disability Standards under the Disability Discrimination Act: Employment Issues', Employment Standards under the Disability Discrimination Act: Resource Paper (Web Page) <https:/www.humanrights.gov.au/publications/employment-standardsunder-disability-discrimination-act-resource-paper $>$. Thus, employers do not need to provide equipment that is primarily for personal benefit. 
reasonable accommodation regime acknowledges that work environments are the result of a series of choices about how work is completed, and that employers can make different choices to accommodate those with a disability. ${ }^{81}$ As in society, disability is constructed in the workplace. $^{82}$

Where a social model understanding is absent, reasonable accommodation regimes are unlikely to be successful. ${ }^{83}$ That some workplaces prove resistant to reasonable accommodations may reflect a pervasive 'ableness' norm that both ignores structural changes that might be successfully made and undervalues the work of people with disabilities. ${ }^{84}$ Where adopted, however, reasonable accommodations have been shown to improve employee retention for those with disabilities. ${ }^{85}$

As noted above, discrimination under the $D D A$ includes a failure to make 'reasonable adjustments' which has, or is likely to have, the effect of treating the person with the disability less favourably. ${ }^{86}$ Further, an employer can only argue the inherent requirements exception to disability discrimination if the worker is unable to carry out the inherent requirements of a position after the employer has made reasonable adjustments for the person with the disability. ${ }^{87}$

Lawson argues that reasonable accommodation regimes entail both a substantive and procedural component: procedurally, they require employers to enter a dialogue with workers to identify an appropriately individualised solution to accommodate their disability; ${ }^{88}$ and substantively, they require employers to provide that solution where possible. As we go on to discuss in Part V, the procedural component that Lawson highlights in the devising of reasonable accommodations, with its dialogic and consultative qualities, is strongly compatible with the way courts tend to work as collegial institutions that respect individual independence.

The substantive requirement to provide an accommodation to the individual with a disability is obviously qualified by the notion of whether it is 'reasonable' to do so. Under the $D D A$ that is tested by reference to the concept of unjustifiable hardship, to which we now turn.

\section{Unjustifiable Hardship}

It is not unlawful for an employer to discriminate against an employee with a disability if avoiding the discrimination would impose an 'unjustifiable hardship' on the employer. ${ }^{89}$ The concept of 'unjustifiable hardship' is defined by the $D D A$ in relation to all the circumstances of a particular case including, 'the nature of the benefit or detriment likely to accrue to, or to be suffered by, any person concerned; the effect of the disability of any person concerned; and the financial circumstances, and the estimated amount of expenditure required to be made, by

Sharon L Harlan and Pamela M Robert, 'The Social Construction of Disability in Organizations: Why Employers Resist Reasonable Accommodation' (1998) 25(4) Work and Occupations 397, 398.

82 Ibid 399.

$83 \quad$ Lawson (n 69) 68

84 Harlan and Robert (n 81).

85 Richard V Burkhauser, J S Butler and Yang Woo Kim, 'The Importance of Employer Accommodation on the Job Duration of Workers with Disabilities: A Hazard Model Approach' (1995) 2(2) Labour Economics 109.

$86 \quad D D A$ (n 66) ss 5(2), 6(2).

87 Ibid s $21 \mathrm{~A}$.

$88 \quad$ Lawson (n 69) 69. See similarly Watts v Australian Postal Corp (2014) 222 FCR 220.

$89 D D A(\mathrm{n} 66) \mathrm{s} 21 \mathrm{~B}$. 
the person to avoid the occurrence of discrimination'. ${ }^{90}$ Importantly, these considerations will determine the availability and extent of what the employer is required to provide in the way of 'reasonable adjustments' so as to avoid the discrimination. This is made clear by the definition of a 'reasonable adjustment' as essentially any adjustment except those the making of which 'would impose an unjustifiable hardship on the person'. ${ }^{91}$ The CRPD frames the same concept as one of reasonable accommodations 'not imposing a disproportionate or undue burden' on the discriminator. ${ }^{92}$

The notion of unjustifiable hardship is illuminating in the judicial context, particularly in revealing the sorts of impacts or accommodations that might be considered in instances of judicial impairment. The impact that a judicial officer with a physical or mental impairment may have upon their colleagues, litigants and even public confidence in the judiciary as a whole might be said to be relevant to the notion of 'unjustifiable hardship' - indeed, the definition explicitly includes benefit or detriment to the community generally..$^{93}$ In the case of adjustments for some conditions - installation of a ramp for a wheelchair, for instance - the benefit to the judge will be obvious and the detriment negligible to any other individuals or the court as an institution. Other, more complex, cases may be more finely balanced.

It is important to resist seeing this as simply a trade-off between making adjustments to avoid discrimination and the cost of doing so (including in the broadest sense). That does not really get to the heart of the social model, which requires a constructive and holistic approach to the question of whether the effect of an individual's impairment effectively renders them unfit for the work required by their office. Even with the provision of adjustments, the issue is less one of burden, whether of financial cost or significant impact on others through altered work practices of some sort, and more one of asking what it is that judicial officers must be able to do in the job. To answer this question, though, requires a better understanding of what the judicial 'job' entails - that is, in discrimination law language, what are the 'inherent requirements' of the position?

\section{Inherent Requirements}

Section 21A of the $D D A$ provides that it is not unlawful for a person to discriminate against another on the basis of the latter's disability in relation to work where 'because of the disability, the aggrieved person would be unable to carry out the inherent requirements of the particular work, even if the relevant employer, principal or partnership made reasonable adjustments for the aggrieved person' ${ }^{94}$ Essentially, as put, the concept of inherent requirements excuses what would otherwise amount to disability discrimination in the workplace.

In the setting of judicial service, a focus on inherent requirements may have a positive function, in interrogating any assumed equivalency between impairment or disability and incapacity. It also requires a more systematic consideration of whether, after making such adjustments as are reasonable to accommodate the relevant impairment or disability, the individual is still able to

Ibid s 11(1).

Ibid s 4 .

$C R P D(\mathrm{n} 79)$ art 2.

$D D A$ (n 66) s 11(1)(a).

The section also provides that in determining whether the 'aggrieved person' would be able to perform the inherent requirements of the position, regard may be had to a range of circumstances including their qualifications and previous experience and 'any other factor that it is reasonable to take into account': Ibid s $21 \mathrm{~A}(2)$. 
meet the necessary standards of judicial performance. Importantly, this is far more searching than traditional, informal practices of exclusion - the 'tap on the shoulder' from well-meaning colleagues, indicating it is time to retire or step aside. This is discussed further below.

The experience of the $D D A$ shows that agreement on the inherent requirements of various occupations can be elusive, indeed strongly disputed, even in a general employment setting. In Qantas Airways Ltd v Christie, ${ }^{95}$ a pilot challenged the termination of his employment at age 60, invoking a statutory prohibition on employers doing so unless it was based on the inherent requirements of the position. ${ }^{96}$ The High Court provided limited guidance on the test to be used to identify the 'inherent requirements' of a position. Indeed, Brennan CJ sought to 'guard against too final a definition of the means by which the inherent nature of a requirement is determined', instead preferring a 'case by case' approach ${ }^{97}$ While all members of the Court regarded an inherent requirement as something 'essential' to the position, their interpretation of that term varied significantly. The Justices also disagreed as to what was 'inherent' in $\mathrm{Mr}$ Christie's particular employment as an airline pilot.

Additionally, there is the danger that focusing on 'inherent requirements' may serve to perpetuate 'ableness' conceptions of what a job entails:

Over time, the jobs themselves are infused with qualities of particular groups of people that are believed to be intrinsic requirements of job tasks. Employers ignore the actual skills, accomplishments, and capabilities of individuals whose culturally defined traits do not match those assigned to particular jobs. ${ }^{98}$

There is little reason to suspect that consensus on the inherent requirements of judicial office will be easily obtained. For one thing, and particularly in Australia with its reluctance to reform judicial appointments processes,${ }^{99}$ there has been a disinclination to clearly state the essential qualities needed in those to be appointed to the bench, let alone a position description articulating the duties and requirements of office. The fullest articulation of desired judicial qualities and skills is probably that proposed by the Australasian Institute of Judicial Administration in 2015 - comprising six broad categories under which numerous specific attributes are listed. ${ }^{100}$ But, as one might expect from a list that aims to be so comprehensive, a question arises as to whether all, or which particular criteria, are truly 'essential' or 'inherent' to the fulfilment of judicial responsibilities. It risks a version of 'ableness' to simply equate a portrayal of the 'ideal' judge, which is arguably the aspiration of such extensive criteria, with the inherent qualities and skills required for judicial work. There is undoubtedly scope for different views as to what may be regarded as 'essential' to the effective performance of judicial duties to the necessary standard.

\section{E Applying a Discrimination Law Lens to Judicial Incapacity}

As valuable as the four-fold concepts of disability, reasonable adjustments, unjustifiable hardship and inherent requirements are to providing dimensional structure to the way we think

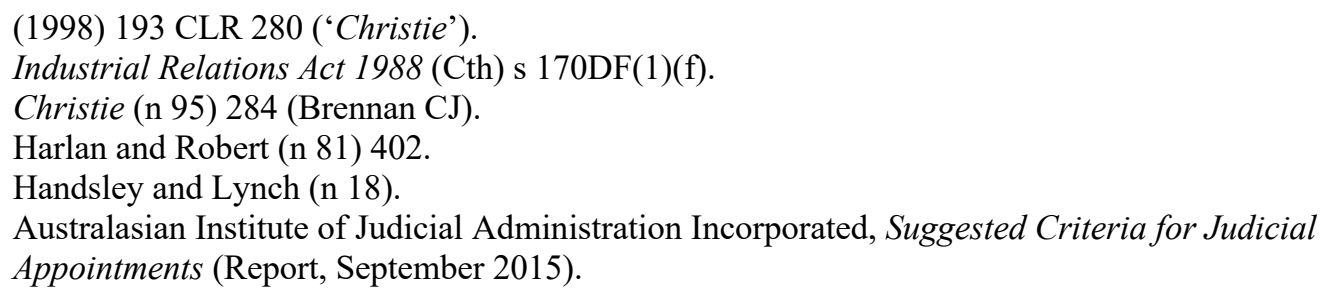


about judicial incapacity, we do not suggest they provide easy answers to the challenges involved. Certainly, it is not suggested that this framework can be simply imported or applied to the context of judicial service without recognising that courts are hardly a typical employment setting; sight must not be lost of the paramount importance of the constitutional principle of judicial independence and the institutional values that necessarily intersect with the circumstances of an individual.

The centrality of judicial independence actually makes even more apparent the benefit of understanding incapacity through reliance on clearly articulated concepts, particularly those which focus as much upon the obligations of the institution as they do the condition of the individual judge. Approaching incapacity in a holistic, social sense and by reference to the standards germane to disability discrimination law - no matter how elusive these may be in practice - must improve the security of individual judges from internal pressure to quietly resign when they acquire an impairment or disability. Recourse to these concepts makes plain the requirement that heads of jurisdiction must 'deal with' an impairment in such a way that, where possible, facilitates the judge remaining in office, even if this may include a suspension from active sitting duties in the immediate term. They would also inform and guide parliamentary consideration, should it come to that, of whether incapacity exists that requires the removal of a judge from office. Over the last 20 years, the New South Wales Parliament has voted against the removal of three judicial officers suffering from mental health conditions; ${ }^{101}$ implicit in that result on repeated occasions appears to be a view that the individual should be provided with adjustments or that, with the correct treatment, there is no impediment to them fulfilling the essential requirements of judicial office or returning to the bench when they are able to do so.

Acknowledging these limitations and potential benefits, then, in the sections that follow we consider how a discrimination law lens might shed light on existing practices around judicial incapacity. Drawing on these ideas, we argue there is a need for more systematic and holistic processes to address and accommodate judicial incapacity.

\section{EXISTING PROCESSES AROUND JUDICIAL INCAPACITY}

Few formalised practices exist to address judicial incapacity in Australia's judiciary. Identifying and managing judicial incapacity and, ultimately, removing a judge on the basis of incapacity may occur through actions taken by either or all of three responsible parties: the judge themselves; the head of the jurisdiction; or some external body (such as parliament).

\section{A Individual Identification and Management}

First, in what might be seen by some as a 'best case' scenario, a judge who acquires or develops a health condition that prevents them from continuing in office will come to that realisation swiftly and resign their commission. In this scenario, identifying and managing incapacity is a judge's personal responsibility, and judicial removal via resignation is a personal decision based on individual judgment. In such cases, the judge's colleagues, the lawyers who appear before them, litigants and the general public may be entirely ignorant of the judge's circumstances. Importantly, by taking the initiative the judge relieves those around them from coming to their own realisation of the incapacity and, should the judge remain in office, the necessity of taking some action in respect of it.

\footnotetext{
101

Campbell and Leee (n 53) 126.
} 
However, the 1979 resignation of Sir Kenneth Jacobs from the High Court of Australia after only five years' service because of a diagnosis of stomach cancer stands as a cautionary example to those who think that this approach must surely avoid all difficulty. Despite the urging of Chief Justice Barwick, Jacobs resigned rather than take leave because the treatment was expected to debilitate him for several months and he was concerned about the impact of his absence on his colleagues and the Court. ${ }^{102}$ In particular, obvious problems can arise if a final court charged with resolving constitutional disputes has to sit as an even numbered bench for more than a short time. But Jacobs had been misdiagnosed, and not only did Jacobs not require cancer treatment, but he went on to reach 97 years of age, until he died in 2015, after reinventing himself as a Wiltshire bookbinder and completing a Masters of Classics at the University of London. ${ }^{103}$

Apart from the importance of getting a second medical opinion, a lesson from the Jacobs story is the value of flexible work arrangements and reasonable accommodations in enabling courts to address the unexpected and accommodate temporary judicial illness - even of a possibly protracted kind. It should be noted that the High Court has since experienced illness amongst its members, but arrangements were made through case allocation by the Chief Justice to manage reduced capacity until the judges returned to good health. ${ }^{104}$

Unlike the step of resignation, arrangements to manage a judge's health issues cannot occur solely at that individual's initiative. A classic example of what we would now call a 'reasonable accommodation' was denied is the refusal in 1976 of the High Court of Australia's Chief Justice Barwick to facilitate Justice Edward McTiernan's return to the court once it became necessary for him to use a wheelchair after he sustained an injury from a fall. ${ }^{105}$ In a decision that is, one would hope, quite unthinkable now, McTiernan's simple request that a ramp be installed in the court to enable him to continue sitting on the bench was denied by Barwick, prompting McTiernan's resignation after 46 years on the court. This episode, handled internally within the Court, did not involve any wider discussion, let alone parliamentary consideration, of whether McTiernan's physical condition satisfied the constitutional ground for removal of 'incapacity'. But it is in fact perfectly clear that McTiernan was not incapacitated in the relevant sense of being effectively unable to carry out his duties. Thus, relying on an ad hoc and informal process for determining reasonable accommodations may effectively deny judges security of tenure, and jeopardise judicial independence within the courts from judicial colleagues.

These stories, while unfortunate, do not illustrate the more fundamental challenges of relying on individual judges to manage their own incapacity. Those may be separately stated as cases where (i) a judge is unaware of their condition and its impact upon the performance of their duties; (ii) a judge is aware of their condition but not its impact upon the performance of their duties; or (iii) a judge is aware of both their condition and its impact upon the performance of

102 Tony Blackshield and Mark Mackrell, 'Jacobs, Kenneth Sydney’ in Tony Blackshield, Michael Coper and George Williams (eds), Oxford Companion to the High Court of Australia (Oxford University Press, 2001) $364,367$.

103 Michael Pelly, “Liberal” Kenneth Jacobs dies at 97', The Australian (online, 5 June 2015) $<$ https:/www.theaustralian.com.au/business/legal-affairs/liberal-kenneth-jacobs-dies-at-97/newsstory/beb9d79fc08d7efc06fb3cc67658d45b>.

104 Richard Ackland, 'Justice Crennan Is Unwell' Justinian (Blog Post, 5 February 2009) $<$ http://justinianarchive.com/1434-article>.

105 Michael Kirby, 'McTiernan, Edward Aloysius' in Tony Blackshield, Michael Coper and George Williams (eds), Oxford Companion to the High Court of Australia (Oxford University Press, 2001) 466, 469. 
their duties, but is disinclined to resign or seek help or some accommodation from their head of jurisdiction. ${ }^{106}$ In all three scenarios, the judge alone is not able or willing to address the situation of his or her incapacity. Some intervention from others is required, whether prompted by a complaint or merely through collegial observation.

\section{B Informal Collegial Management}

In the second model, then, another party is required to help identify and/or manage judicial incapacity. Typically, this would be the head of jurisdiction, but it could equally be another colleague or peer. Traditionally, this form of intervention has occurred via an informal 'tap on the shoulder' method. Judges living with a physical or mental condition that others perceive to be affecting their fitness for office have traditionally been led, whether through friendly concern or rather stronger pressure, to the conclusion that it is time they simply departed the bench. The circumstances under which McTiernan departed the High Court may be seen as an example of such a case.

The general reliance on an informal 'tap on the shoulder' may reflect an understandable reluctance to respond to problems of judicial incapacity through the constitutional mechanism for the removal of judges, which admits of no real distinction between cases of misbehaviour and those of incapacity, and which seems crudely ill-suited for application to judges suffering from health problems. By contrast, the 'tap on the shoulder' method may address some of the limitations of relying on judges to identify their own incapacity. In his very brief remarks on incapacity in Judicial Ethics in Australia, Justice Thomas wrote:

I know of several instances where it has become obvious to others, but not to the judge himself, that his abilities have seriously diminished. In some instances a trusted colleague has taken on the unpleasant task of speaking privately with the judge, telling him that it is the view of more than a few that he is no longer performing well, and suggesting that he might lose a fine reputation if he carries on. In each instance, this has been followed by a timely resignation ... In the ordinary case of a judge in the twilight zone, I can think of no better solution than a discreet appeal to the judge's decency and self-esteem. ${ }^{107}$

Doubtless this kind of treatment may be well-meant. It also has the benefit, as Thomas argues, of discretion and privacy, especially when contrasted with parliamentary removal in the absence of some lesser mechanism for responding to shortcomings in judicial performance. But even so, such an informal - even 'clubby' - approach cannot seriously suffice as the only answer to the question of how judicial incapacity should be handled. For one thing, and this must certainly be likely in respect of some cases of mental illness, the individual judge may be far from receptive to suggestions that they are no longer up to the work. A former Chief Justice of Australia acknowledged that 'although they can usually be persuaded to resign there have been instances in which judges, unfit by reason of serious and permanent illness, have resisted

\footnotetext{
106 The situation in which a judicial officer is incapacitated not only from serving but also from resigning need not be addressed, though interestingly this circumstance has been the subject of attention in the United Kingdom. Section 11(8) and (9) of the Senior Courts Act 1981 (UK) empowers the Lord Chancellor to vacate the office of a senior judge in such a predicament with the concurrence of various other senior judges; this effectively effectuates a resignation. Thomas (n 20) 56.
} 
persuasion for too long' ${ }^{108}$ A foremost example, in which efforts at persuasion would have been especially difficult given the status of the affected judge, is the case of Chief Justice William Mack of the Supreme Court of Queensland, who suffered a serious and debilitating stroke in 1969 but did not resign from office until two years later. ${ }^{109}$ Possibly even more awkward, would have been attempts to convince Chief Justice H V Evatt of the Supreme Court of New South Wales, but also formerly a Justice of the High Court of Australia, before intervening years as Commonwealth Attorney-General and Federal Opposition Leader, that his mental deterioration rendered him unfit to serve. ${ }^{110}$ In cases not involving the head of jurisdiction, judges still may be unwilling to have 'difficult conversations' with their peers, and may avoid broaching issues of impairment at a time when reasonable accommodations could or should be made to avoid incapacity.

A different and more substantive complaint about reliance upon the 'unpleasant' private conversation is that it does not necessarily enable consideration of possible solutions to the judge's impairment other than their departure from the court. Many conditions may be manageable with treatment. As Appleby and Le Mire have noted, in Australia the 'most frequent cause of incapacity-based complaints against judges has been ongoing, but treatable, mental illness'. ${ }^{111}$ They conclude that 'provided judges do not sit during this period, passing incapacity should not have an ongoing effect on the public confidence in the system'. ${ }^{112}$ Whilst still President of the New South Wales Court of Appeal, Justice Kirby candidly identified the many diverse causes of judicial stress and suggested a range of, often very simple, methods by which it might be alleviated. ${ }^{113}$ Given the role of stress in triggering or exacerbating poor mental health, resort to strategies of that kind might be attempted in the first instance. Other variations to a judge's working routine or the provision of some specific administrative or technical support would seem only sensible before pointing a judicial officer towards retirement or cranking up the constitutional conveyer belt towards removal.

In practice, we might assume that an afflicted individual may indeed receive this kind of advice, support and accommodation from their head of jurisdiction or other concerned colleagues. But, as with most informal arrangements, doubts justifiably exist over the fairness, consistency and effectiveness with which they are administered. The preference for an informal tap on the shoulder of the judge whose performance is affected by disability or diminished health excuses the court of any onus to assist the judicial officer to perform the duties of office. That is bad enough by itself, but in so doing, the practice displays a concerning attitude toward the importance of the principle of judicial independence, specifically the aspect of that principle which recognises judicial officers should be, to a large extent, independent of undue influence and pressure from their colleagues.

\footnotetext{
108 Harry Gibbs, 'The Appointment and Removal of Judges' (1987) 17(3) Federal Law Review 141, 146-7. See also Shetreet and Turenne (n 25) 288-9.

109 Thomas (n 20) 55.

110 There would have also been a cruel irony in doing so, since Evatt's condition was in fact instrumental in his being appointed to the Court by the New South Wales Labor government, as an inducement for him to vacate the leadership of the federal party. The state Attorney-General strongly opposed Evatt's appointment 'because of his mental and physical declinement' (at 373) but eventually yielded to party pressure. Evatt's incapacity was almost immediately evident and imposed a great burden on the judges of the court who both covered for, and worked around, him: John Murphy, Evatt: A Life (NewSouth Publishing, 2016) 373-8.

111 Appleby and Le Mire (n 5) 10.

112 Ibid 11

113 Kirby, 'Judicial Stress' (n 9) 13-14.
} 
Conversely, we should recognise that respect for this principle may inhibit or put off the making of an effective response to capacity issues when one is really called for. This was an aspect of the case of Justice Vince Bruce of the New South Wales Supreme Court, whose mental health issues affected his ability to deliver timely judgments in the mid-1990s. Chief Justice Murray Gleeson, having been assured that Bruce 'was okay' after arranging 'for a friend of the judge to check up on him' was, says his biographer, initially 'reluctant to do any more, lest he be accused of interfering with judicial independence'. ${ }^{114}$ A reluctance to respond effectively to capacity issues may also increase reliance on mandatory retirement as a judicial management tool. This is a largely ineffective means of securing judicial capacity, as it does not address the underlying issue, makes no provision to support or mediate the impact of infirmity on a judge's performance, and likely leads to worse performance of the judiciary as a whole, as little is done while awaiting the date of retirement. Thus, this flags the need for a more structured, less ad hoc approach to issues of infirmity.

Despite this, the informal 'tap on the shoulder' method was effectively given a legislative basis in the federal jurisdiction via the remarkably vague text added in 2012 to the legislation underpinning the three federal courts in Australia by the Courts Legislation Amendment (Judicial Complaints) Act 2012 (Cth). The purpose of that Act was simply to provide a clearer statutory basis for heads of jurisdiction to address complaints about judicial officers in their courts, and to give them legal protection in so doing. The Act enables the head of jurisdiction of the Federal Court, Family Court and Federal Circuit Court to 'deal' with a complaint by 'handling' the complaint when possessed of a 'relevant belief' in relation to it. ${ }^{15}$ 'Relevant belief' is defined to mean a belief that the circumstances that gave rise to the complaint may, if substantiated (i) justify consideration of the removal of the Judge in accordance with paragraph 72(ii) of the Constitution; (ii) adversely affect, or have adversely affected, the performance of judicial or official duties by the Judge; or (iii) have the capacity to adversely affect, or have adversely affected, the reputation of the Court. ${ }^{116}$ To 'handle' a complaint is defined expansively but without any specificity. The most open-ended of the acts included in the meaning of 'handle' is to 'deal with a report of an investigation of the complaint'. ${ }^{117}$ But elsewhere the amendments empowered the heads of jurisdiction to 'take any measures' they believe 'are reasonably necessary to maintain public confidence in the Court, including, but not limited to, temporarily restricting another Judge to non-sitting duties'. ${ }^{118}$

In aiming merely to create a legislative basis for the informal system that was operating in the three federal courts, the 2012 amendments fail to supply any clarity to the area beyond the empowerment of the head of jurisdiction. In only one respect is that particularised - to temporarily restrict a judge to non-sitting duties. It seems worryingly loose to confer such a significant statutory power, dependent simply on the belief of the head of jurisdiction that such a course is 'reasonably necessary to maintain public confidence in the Court'. ${ }^{119}$ As Appleby and Le Mire lament,

\footnotetext{
114 Michael Pelly, Murray Gleeson: The Smiler (Federation Press, 2014) 182.

115 Federal Court of Australia Act 1976 (Cth) s 15(1AAA)(a)(ii); Family Court of Australia Act 1975 (Cth) s 21B(1B)(a)(ii); Federal Circuit Court Act 1999 (Cth) s 12(3AA)(ii).

116 Federal Court of Australia Act 1976 (Cth) s 4; Family Court of Australia Act 1975 (Cth) s 4(1); Federal Circuit Court Act 1999 (Cth) s 5.

117 Federal Court of Australia Act 1976 (Cth) s 4; Family Court of Australia Act 1975 (Cth) s 4(1); Federal Circuit Court Act 1999 (Cth) s 5.

118 Federal Court of Australia Act 1976 (Cth) s 15(1AA)(d); Family Court of Australia Act 1975 (Cth) s 21B(1A)(d); Federal Circuit Court Act 1999 (Cth) s 12(3(d).

119 See discussion in Andrew Lynch, 'Judicial Complaints and Suspension' (2012) 23(2) Public Law Review 81 .
} 
there is no other indication about the types of responses that may be made to a complaint - such as issuing a public admonishment or reprimand, or requiring mandatory judicial education. No guiding criteria are provided to assist the head of jurisdiction, or persons making a complaint, to determine what might fall across the line as inappropriate behaviour. ${ }^{120}$

Relevantly for present purposes, the Commonwealth legislation is a classic example of the failure to afford any express recognition to capacity issues; instead these are simply subsumed within the notion of 'complaints'. The need for a 'complaint' as a catalyst for the powers of the head of jurisdiction (as the foremost 'complaint handler') appears to immediately problematise issues around judicial incapacity and suggests that heads of jurisdiction may not take the initiative to address issues of incapacity. The source of such complaints is not specified; would the concerns of colleagues about a judicial officer's capacity fall within the concept, or must the concern be raised by litigants or their counsel? Does the open-ended power to 'take any measures' suffice to provide the head of jurisdiction with the ability to request a judicial officer undergo a physical or mental examination? Could such an examination actually be required by making it a condition of allowing the judge to continue sitting? On these specific questions, as well as so many others, the legislation is silent.

An alternative to the 'tap on the shoulder' is public exposure for underperformance, including via the release of performance data. Consider, for example, submissions to the Australian Law Reform Commission's 2000 review of the federal civil justice system. It was clear that 'the power of public disgrace', ${ }^{121}$ as one federal court judge expressed it, was widely seen as a sufficient and acceptable means by which problems of judicial performance may ultimately be resolved. The submission of the Law Council of Australia was particularly instructive in this regard:

[T] he most effective way of dealing with perceived recalcitrant judicial behaviour is exposure of that behaviour and peer pressure. Sanctions in any form (including mandatory judicial education) are neither desirable nor appropriate. By 'exposure', the Law Council means through the transparency afforded by the publication of court data which demonstrate judicial performance through indicators such as sitting days, sitting times, numbers of outstanding judgments and periods of time for outstanding judgments. ${ }^{122}$

This passage gives a good indication of how easy it is to fail to appreciate that poor judicial performance may have different causes, and that there is a clear distinction between 'misbehaviour' and 'incapacity'. The problem being discussed - delay in the delivery of judgments - is one that is probably much more likely to stem from issues of capacity rather than wilful 'misbehaviour'. But with no recognition of this, the solution advanced by the Law

\footnotetext{
$120 \quad$ Appleby and Le Mire (n 5) 32.

121 Margaret Beazley 'Judicial Independence and Accountability: A Discordant Couplet' (Conference Paper, Australian Institute of Judicial Administration Annual Conference, 6-8 August 1999) 10-12.

122 Law Council of Australia, Submission No 375 to the Australian Law Reform Commission, Parliament of Australia, Review of the Federal Civil Justice System, quoted in Australian Law Reform Commission, Managing Justice: A Review of the Federal Civil Justice System (Report No ALRC 89, 31 December 1999) 221.
} 
Council - 'exposure' or essentially 'shaming' - seems both crude in its indifference to capacity issues and harsh upon those against whom it is employed. ${ }^{123}$

\section{Formalised Intervention by Third Parties}

Finally, and third, a more formalised process might be used to allow intervention and management of judicial incapacity by third parties. The traditional example of this is the removal of incapacitated judges by the Governor-General upon an address to both houses of Parliament, as discussed in Part II. While use of parliamentary removal is a blunt tool for dealing with misbehaviour, ${ }^{124}$ it is arguably even more inappropriate for managing incapacity. First, the parliamentary process is rarely used to address judicial incapacity, meaning many issues are left unaddressed and unresolved. Second, the process makes no provision for reasonable accommodations or attempts to minimise the impacts of a disability, in accordance with the social model. Third, the process is public and, like the release of performance data, entails a significant component of public shaming and humiliation. This is inherently unsuitable for managing issues of incapacity, and may exacerbate mental health issues. Thus, there is a need for alternative processes to manage incapacity, which are of a lesser order than parliamentary removal. Formal complaint-handling processes may offer one alternative.

Formal complaint-handling processes that empower the judiciary to investigate and make recommendations concerning individual judicial officers are, by their nature, a deliberate qualification upon the operation of judicial independence. However, in only one Australian jurisdiction is the performance of individual judicial officers subject to a sophisticated system of collegial oversight. The Judicial Commission of New South Wales was established in 1986, and powers to investigate non-trivial complaints were given to a Conduct Division of the Commission. If the Division finds a complaint to be wholly or partly substantiated it can report to the Governor its view that the matter could justify parliamentary consideration of removal or it may refer the matter back to the head of jurisdiction, possibly with recommendations 'as to what steps might be taken to deal with the complaint'. ${ }^{125}$ As originally enacted, this legislation bore out the earlier observation that traditionally incapacity has been subsumed by procedures that are more obviously designed to respond to allegations of misconduct. The only exception to this, and an acknowledgment of the potential impact of health problems, lay in the power of the Conduct Division to request a judicial officer to undergo a medical examination when of the opinion that they 'may be physically or mentally unfit to exercise efficiently the functions of a judicial office'. ${ }^{126}$ The Conduct Division may have regard to any refusal or failure of the judicial officer to undergo the medical examination in forming an opinion that the matter could justify parliamentary consideration of the removal of the officer from office. ${ }^{127}$

That provision remains in force - though it now refers to a 'medical or psychological examination'. This power (limited essentially to making a request) may have resulted in the Conduct Division having a clearer understanding of the reasons for the judicial officer's behaviour but it otherwise did not form part of a more systemic approach to specific issues of capacity. That deficiency was addressed by the 2006 addition to the Judicial Officers Act 1986 (NSW) ('Judicial Officers Act') of a new Part titled 'Suspected Impairment of judicial officers'.

\footnotetext{
123 This is not to argue that information of the kind described by the Law Council should not be made publicly available - it should, but not as a strategy by which incapacity is primarily addressed.

Appleby and Le Mire (n 5).

Judicial Officers Act 1986 (NSW) s 28(1)-(3).

Ibid s 34(1).

Ibid s 34(2).
} 
This created a pathway for such issues to be investigated by the Commission at the request of a head of jurisdiction, absent any formal complaint: indeed, the legislation explicitly confirms that such a request 'is not a complaint'. ${ }^{128}$ The Commission is to conduct a preliminary examination in response to the request, and the examination and any inquiries made under it 'must, as far as practicable, take place in private'. ${ }^{129}$ In a significant enhancement of the power to request a judicial officer undergo a medical or psychological examination in response to a complaint, the Commission 'may require the judicial officer concerned to undergo such medical or psychological examination as the Commission specifies'. ${ }^{130}$ Should the judicial officer refuse or fail to comply in this respect, the Commission may proceed to treat the matter as if it were a complaint.

The conversion of the issue to what might be described as the Commission's regular 'disciplinary mode' obviously exposes the individual to some unattractive consequences, not the least being greater publicity and possible culmination of the affair in a parliamentary motion of removal. But these dangers are ones that the judicial officer may still face even if they undergo the relevant medical or psychological check-up. If, at the conclusion of the preliminary examination, the Commission is 'of the opinion that, having regard to the results of a medical or psychological examination, the judicial officer may have an impairment that affects his or her performance of judicial or official duties', it may refer the matter (with the results of the medical or psychological examination) to either the Conduct Division or back to the head of jurisdiction. If, after its own investigation, the Conduct Division arrives at a conclusion similar to that reached by the Commission, it must present a report to the Governor that the judicial officer's condition could justify parliamentary consideration of their removal from office. ${ }^{131}$

To the extent that the attempt to handle concerns about judicial impairment with privacy and sensitivity can still potentially lead to a parliamentary motion of removal, this is not only inevitable but also appropriate, given the constitutional qualifications upon judicial security of tenure. But whether that ultimate resolution is the right one will depend greatly on the specific circumstances of the individual case and the assumptions that are brought to bear upon them. This depends on how broadly the standard of 'incapacity' may be conceived. A discussion about how those assumptions may be more consciously framed and considered by those investigating a suspected impairment occurs in the next and final part of this paper.

Importantly, judicial officers in NSW who are disinclined to quietly resign their commission after a 'tap on the shoulder' from colleagues do not, in the alternative, face the prospect of being driven inexorably towards having to defend themselves against a parliamentary motion for removal. The Judicial Officers Act creates a third option, by providing that both the Commission and the Conduct Division may return the matter to the head of jurisdiction who made the initial request. There is a subtle difference in the respective position of each when doing so. The Commission may form the opinion that the judicial officer 'may have an impairment that affects his or her performance of judicial or official duties' and yet still decide not to refer the matter to the Conduct Division from which possible removal might result. ${ }^{132}$ By contrast, if the matter has gone to the Conduct Division, it can only refer it back to the head of jurisdiction if it is " $n o t$ of the opinion that the judicial officer is physically or mentally unfit

Ibid s 39B(2).

Ibid s 39C(3).

Ibid s 39D(1).

Ibid s 39G(1).

Ibid s 39E(3). 
to exercise efficiently the functions of a judicial office'. ${ }^{133}$ On its face, the latter appears less accommodating of the judge's physical or mental impairment, but in practice, again, much may depend on what the Conduct Division infers from the standard of exercising 'efficiently the functions of a judicial office'.

Referral back to the office holder who raised the suspicion of physical or mental impairment may seem circular or a non-solution. But in either case, the Commission or Conduct Division 'may include recommendations as to what steps might be taken to deal with any impairment disclosed by the ... examination of the matter'. ${ }^{134}$ Although the head of jurisdiction is not expressly required under the legislation to 'deal with any impairment', it is implicit that by rerouting the matter away from the path of removal, some accommodation of the judicial officer's condition, so as to allow them to continue to serve, is regarded by the referring body as feasible. In other words, the head of jurisdiction is to take the necessary steps to avoid the judicial officer's impairment acquiring the status of incapacity.

\section{DESIGNING A PROCESS TO ADDRESS JUDICIAL INCAPACITY}

\section{A Key Features of a Process to Address Judicial Incapacity}

Applying a discrimination law lens, we argue for a fresh conceptualisation of judicial incapacity based on several key features. Fundamentally, incapacity needs to be understood in accordance with the social model of disability, emphasising the structural and public aspects of incapacity, and reinforcing the court's moral responsibility for assisting and supporting judges who experience such issues, in a way that respects judges' individual agency and judicial independence. This is in contrast to the traditional approach of viewing the judge as medically impaired and therefore unfit to continue in office. The whole 'process' of addressing and supporting judges in these circumstances needs to reflect a holistic understanding of disability, with clear guidance given to heads of jurisdiction regarding their responsibility to take such steps as will enable the continued service of judicial colleagues where these may be available. The extent to which reasonable accommodations can be implemented should be determined by an inclusive and ongoing dialogue between the individual and the head of jurisdiction, with a focus on identifying individualised solutions that also accommodate the operational needs of the Court wherever possible.

When we approach incapacity in this way, the limitations of current statutory models, detailed above, come into stark relief. In addition to the deficiencies of the Courts Legislation Amendment (Judicial Complaints) Act 2012 (Cth) that were identified in Part V, the fundamental shortcoming of the legislation is that it gives no guidance that cases of judicial impairment should be approached holistically, with an obligation on the head of jurisdiction and court administrators to find ways of supporting a judge to remain in office where that is possible. Reasonable accommodation is simply not required as a response to judicial impairment within the Commonwealth court system. Consider, by contrast, the New South Wales provision that refers to the head of jurisdiction having to 'deal with the impairment'. While unhelpfully basic, it is possible to view this as implying an obligation to respond to an instance of judicial physical or mental incapacity by examining the possibility of reasonable accommodation. If so, this challenges the historical and cultural equivalence between judicial impairment and judicial incapacity. But the Commonwealth law, in merely placing a statutory

133 Ibid s 39G(3) (emphasis added).

134 Ibid ss 39E(3), 39G(4). 
veneer over traditional practices, is both a missed opportunity and a new danger. Obviously, the opportunity missed is the construction of a modern approach to the issue of judicial incapacity - one that is in step with contemporary employment and discrimination law by being nuanced, inclusive and fairer. Not only would this show more respect to judicial officers with a physical or mental condition, it would offer them better protection from internal pressure to resign. This takes us to the danger - by statutorily empowering heads of jurisdiction in such an uncircumscribed fashion, the Commonwealth law carries the potential for a threat to individual judicial independence.

Typically, the principle of judicial independence has been used, at least in Australia, to resist moves to develop systems around judicial complaints and performance. As Sir Harry Gibbs said, it is:

essential that judges in the performance of their judicial functions should be completely free of pressure or influence from the administration, the legislature or anyone else. The security of tenure which English judges have enjoyed since the Act of Settlement, which is guaranteed to federal judges by the United States Constitution, and which Australian judges also enjoy, is a necessary protection against political and other pressure and influence and it is important that it should not be weakened by whatever measures are taken to deal with complaints of misconduct or incapacity. ${ }^{135}$

Perfect insulation of a judge from the pressure that attends responding to concerns about their conduct or capacity is, of course, impossible. The principle of judicial independence cannot trump what Gibbs acknowledged as 'the obvious need that a person entrusted with functions as important as those of a judge should be fit to perform them'. ${ }^{136}$ Accepting that tradeoff requires the development of a properly articulated complaints system (for want of a better shorthand expression) - rather than statutory affirmation of traditional informal practices. The contrast is between, on the one hand, a system in which the powers that may be used in respect of the individual judge who is under scrutiny are stated with specificity and are underpinned by clear principles and, on the other, one in which the 'tap on the shoulder' is made with statutory backing - the weight of a heavy hand indeed. Measured against those contrasting approaches, the New South Wales legislative scheme is superior to that of the Commonwealth. But neither system is underpinned by an inclusive or holistic framework or principles to sufficiently guide responses to the issue of potential judicial incapacity. The necessary power is there for responses of whatever kind one may imagine, but so long as this is unguided we should be alert to its potentially unfair use against an individual judicial officer, in such a way that may undermine the principle of judicial independence more generally.

Ultimately, the framework must acknowledge that a permanent or temporary impairment need not spell the end of a judge's career. This is so, first and most obviously, when the judge is able to continue carrying out their duties without interruption, despite the affliction and absent any accommodation at all being made. In such cases the individual's disability simply does not impact upon their capacity. Blom-Cooper gives the example of Lord Justice Sedley, whose suffering from mild tinnitus, a condition affecting hearing, was not incompatible with his 
fulfilment of the responsibilities of a member of the English Court of Appeal, though this might be a condition that would present stronger challenges in trial adjudication. ${ }^{137}$

Whether a judge is capable of carrying out their duties without interruption will depend on how we conceive of that role and duties. As discussed in Part IV, what constitutes the inherent requirements' of the judicial role is a question that is capable of being answered with varying degrees of breadth. As reflected in the comprehensive Suggested Criteria for Judicial Appointments proposed by the Australasian Institute of Judicial Administration, some attributes will receive greater emphasis over time and become regarded as more 'essential' than was previously the case. It is also possible to refer to standards of behaviour that are themselves flexible. Consider, for example, the view of the Conduct Division of the Judicial Commission of New South Wales that removal on the basis of incapacity must be understood as 'incapacity to discharge the duties of judicial office in a manner that accords with recognised standards of judicial propriety'. ${ }^{138}$ This subsumes the question of incapacity to the contemporary professional behavioural standards of the judiciary - including, in that particular case, 'affording a fair hearing to all litigants, avoiding offensive remarks and bullying, and maintaining, in the court room, the decorum that enhances respect for the judicial decisionmaking process...' ${ }^{139}$ After couching the concept of the requirements of judicial office in this way, the inquiry of the Judicial Commission into complaints against New South Wales Magistrate Jennifer Betts concluded that incapacity had been proved 'because she [the Magistrate] has demonstrated a failure to understand quite basic standards of judicial behaviour'. ${ }^{140}$

Just how narrowly or broadly we conceive what is necessary for the effective discharge of judicial duties obviously has a hydraulic effect upon the incidence of incapacity. The standard applied in the Betts case would mean that judicial officers whose condition nevertheless enables them to sit, hear and decide cases, may still be regarded as incapable of fulfilling the requirements of the job and thus vulnerable to removal. But if some more essentialist understanding of the performance of judicial duties is taken, those same judicial officers may not be so exposed. Problematic issues stemming from the judicial officer's health obviously should not go unaddressed - but the issues in question might be more constructively approached than through the prism of incapacity, with its focus upon removal.

The question remains, then, as to what capacities are essential to the judicial role: what are the inherent requirements of the position? Of particular importance to judicial work are the senses of sight and sound. It is hardly controversial to say that a diminished capacity to read, see witnesses and jurors, and hear oral argument and evidence may negatively affect judicial performance, even conceivably to such a degree that it may at first appear to be plain dereliction. The decline of the faculties of vision and hearing is often incremental, and will not be obviously apparent for some time, perhaps even to the judge themselves. For this reason, Blom-Cooper accepted the wisdom of 'compulsory retirement at an age commensurate with scientific (medical) knowledge of the ageing human condition', but also acknowledged that

\footnotetext{
137 Louis Blom-Cooper, 'The Age of Judicial Responsibility: The Retirement and Resignation of Appellate Court Judges' in Shimon Shetreet and Christopher Forsyth (eds), The Culture of Judicial Independence: Conceptual Foundations and Practical Challenges (Martinus Nijhoff Publishers, 2011) 339, 345.

138 Conduct Division (n 65) 53-4.

$139 \quad$ Ibid 54

140 Ibid $72-3$.
} 
some physical capacities 'are infinitely more pertinent to the trial judge than to his [or her] appellate counterpart'. ${ }^{141}$

Arguably, however, it is fairly straightforward to provide reasonable accommodations for some impairment of sight or hearing, such as providing hearing loops in courtrooms, AUSLAN signing, ${ }^{142}$ electronic readers or devices for magnification of text. But the adoption of even measures such as these may be seen as insufficient to ensure the judicial officer meets the inherent requirements of their position. For some, a trial judge being unable to see and visually scrutinise a witness may mean they are unable to assess the veracity of testimony. Such views must be carefully examined as to whether they simply reflect the able-bodied norm of the judicial position, where any alternative accommodations for those with impairments are seen as impossible or impracticable. Resistance to reasonable accommodations should be tested for signs of a limited openness to ways in which essential judicial functions can be reconceived or recast to accommodate those with disabilities.

Regardless as to where one stands on the importance of hearing and sight to the judicial role, this example flags the possibility that a court may be able to adopt measures that avoid a judge's disability amounting to incapacity. In other words, a true assessment of incapacity furnishing a ground for removal should occur not simply in light of the court's existing practices for allocating, hearing and deciding cases, but instead take into account all the possible accommodations that might be made to support the individual judge to perform the essential duties of office, consistent with the social model of disability. The McTiernan story is the most blatant example of inflexible court administration converting a judge's irrelevant impairment into incapacity. Whether an individual's condition truly incapacitates them from performing judicial duties to the necessary standard will usually be harder to answer than in that case, but the essential question is the same. Thus, the context in which judges perform their duties and the extent to which they can do so with reasonable accommodation and support is essential for determining whether an impairment or disability relevantly affects their capacity to hold office.

In this respect, the more complex circumstances of the aforementioned case of Justice Bruce highlight the challenges involved more usefully than McTiernan J's ouster from the High Court. Bruce's battles with major depression following an earlier motor vehicle accident caused significant delays in his delivery of judgments. Following a recommendation by the Conduct Division of the Judicial Commission of New South Wales, a parliamentary motion was made for Bruce's removal from the Supreme Court. In his address to the upper house against his removal for incapacity, Bruce gave a detailed statement of the accommodation and support offered by his heads of jurisdiction:

I made an arrangement with Justice Wood [the new Chief Judge of the Common Law Division of which Bruce was a member] to report to him weekly on what I had done and on the state of my outstanding judgments. I did not regard that as being in any way a diminution of my status as a justice of the Supreme Court of New South Wales, but, rather, as a practical way of ensuring that in future I performed my duties in a timely

$141 \quad$ Blom-Cooper (n 137) 344-5.

142 The High Court dismissed an appeal from a decision of the Queensland Court of Appeal that exclusion of a deaf person from jury service was not a breach of the state anti-discrimination law: Lyons v Queensland (2016) 259 CLR 518. In so finding, the Court focused on the issues arising from the presence of an AUSLAN interpreter in the jury room; this is not a matter that has equivalence to the use that a judicial officer may make of such an accommodation. 
fashion. Justice Wood, for whom I have the greatest respect and admiration, readily agreed, and that is how I propose to carry out my work in future.

... I had a number of discussions with the then Chief Justice of New South Wales, now Chief Justice of Australia, Murray Gleeson. We talked about my condition and about how I should address my outstanding work. The Chief Justice was incredibly supportive, and we discussed techniques and approaches at considerable length. The Chief Justice offered me the use of his research assistant and offered to talk over problems that I might encounter in the course of writing any outstanding judgments. Justice Wood made a similar offer. I did not, in the event, avail myself of those kind offers but set about writing the outstanding judgments. But the mere fact that two of the most senior and respected members of the court were prepared to assist me in that way affected my perception of myself and my perception of how strong people view those who have been ill. I spoke to the Chief Justice about establishing a program by which the outstanding work could be dealt with. I prepared a list of judgments, put them into order, and fixed dates by which they were to be delivered.

The Chief Justice and I agreed that I would sit for only limited periods until those judgments were completed. The judgments were listed in ascending order of difficulty so that I could, for my own feeling of wellbeing, get back onto my bike and start disposing of judgments and work up to the more difficult cases. The last two judgments on the list were, we agreed, cases which required two weeks of uninterrupted work to do them justice - to produce judgments which were appropriate for the complexity of the matters ... The list provided that I was not to sit until 9 March 1998, when I would hear a case which was set down for that week. ${ }^{143}$

For reasons that Bruce went on to explain, a number of factors - both the professional needs of the Court and the exacerbation of an existing medical complaint - interfered somewhat with the plan that he would not sit and instead focus on judgment writing. ${ }^{144}$ But nevertheless, he told the Legislative Council that he had exceeded the number of judgments that he had agreed with the Chief Justice to complete. Bruce also invoked medical evidence as to his fitness for office going forward, including from doctors that the Judicial Commission had sent him to be examined by. The Commission itself had split 2:1 on whether there were grounds for Parliament to consider removal. ${ }^{145}$ For these various reasons, as well as Bruce's appeal to the chamber not to stigmatise those who have suffered from mental illness, ${ }^{146}$ it is perhaps not surprising that the motion failed, with the Legislative Council voting 24:16 against Bruce's dismissal. To the extent that the support and offered adjustments made it possible for Bruce to address his backlog of judgments, the vote to allow him to continue in office may be viewed as an affirmation of his capacity when supported through the period of his illness. Unfortunately, however, the judge resigned from the Court less than a year later. Without knowing his particular reasons for doing so, Bruce's resignation may be seen to point to the relevance of sustainability (both for the individual and the institution) when assessing the accommodations to be made in order to assist judicial officers to carry out their functions. This is discussed further in the next section.

\footnotetext{
143 New South Wales, Parliamentary Debates, Legislative Council, 16 June 1998, 5865 (Justice Vince Bruce).

$144 \quad$ Ibid 5866.

$145 \quad$ See Campbell and Lee (n 53) 126.

146 New South Wales, Parliamentary Debates, Legislative Council, 16 June 1998, 5863 (Vince Bruce).
} 
If the question of incapacity is assessed through a fully contextual appraisal of the individual's ability to carry out the central responsibilities of judicial office when supported either by changes to the court's work practices or the provision of greater technical or administrative support, then clearly the identification of a judge's infirmity is simply preliminary to - and distinct from - identification of their incapacity. The latter is a matter that is not determined by a consideration of the judge's condition alone (except, perhaps, in the most obvious cases such as a complete inability to sit); instead, the court's institutional response and the availability of accommodations to support the judge are a substantial aspect of the question of what judicial duties they are capable of performing.

Accordingly, the issue of the court's response needs to be appreciated as not merely reactive, but in fact intrinsic to the question of judicial incapacity. This is almost never acknowledged in controversies over incapacity, the statutory processes that have been developed as a precursor to the constitutional mechanism of removal, or in the associated secondary literature. Yet this is the standard that is required by a social model of disability, and the approach that is increasingly adopted by modern workplaces. As public institutions committed to equality under the law and fairness, courts cannot simply be exempt.

\section{B $\quad$ A More Principled System for Responding to Judicial Incapacity}

Thus, there is a need to move to a more principled system for responding to judicial incapacity, which clearly identifies that reasonable accommodations may be requested and provided to assist judges with an impairment; focuses on the inherent requirements of the judicial position; and protects judicial independence. This could take the form of a structured programme of disability management - which seeks to both prevent disability from occurring, and to intervene early upon the onset of a disability - reflecting a commitment to promoting judicial retention and achieving 'optimal' return-to-work when impairment occurs. ${ }^{147}$ An effective disability management programme can also help to reduce sick-leave costs and improve work productivity. ${ }^{148}$ To effectively implement a disability management programme for the judiciary, however, requires judges and legislatures to overcome the 'ableness' norm that is prevalent in existing judicial culture, ${ }^{149}$ and most obviously evident in how we conceive of the 'inherent requirements' of the judicial role. We need to move beyond the norms of judicial work - which ignore the possibility of structural changes that could accommodate individual impairments - and instead focus on creating and actively seeking solutions that may prevent and address judicial incapacity.

Just what such a disability management programme might look like, and what specific processes and resources should be a feature of it, is a matter beyond the scope of this article. Obviously, it is important to preserve sufficient flexibility in order to respond to a judge's specific needs and circumstances. The sorts of things that the heads of jurisdiction offered Justice Bruce may well be relevant in many cases - this includes structured, collegial support in the form of work plans and regular meetings; relief from sitting duties for a time, or at least from being required to go on circuit and so be away from home and treating physicians; and the provision of additional research assistance. But these are just some obvious examples and

\footnotetext{
${ }^{147}$ Rochelle Habeck and H Hunt, 'Disability Management Perspectives: Developing Accommodating Work 148 Ibid. Environments through Disability Management' (1999) 25 American Rehabilitation 18, 18.

${ }^{148}$ Harlan and Robert (n 81).
} 
other accommodations, possibly of low cost and less disruptive, may be all that is required to ensure retention and performance of the individual.

More broadly, there are critical design questions about how such disability management is to be accessed and how individual plans can be devised. Those issues need to be approached with stakeholder input, most obviously from the judiciary itself, though also from accessibility and inclusion experts and health professionals. What role, if any, these other actors might actually play in the ongoing operation of such a programme is itself a question that would require serious consideration in the development of new mechanisms for supporting and accommodating judicial impairment. However, it is foreseeable that expert input might be required to assist with, for example, identifying relevant technology that may address or minimise the impact of particular infirmities on the judicial role.

Developing a system of this nature requires a context-specific approach, tailored to the circumstances of each jurisdiction, in a way that protects and bolsters judicial independence. In the first instance, guidance and recommendations could be developed by the Judicial Conference of Australia or the Council of Chief Justices, providing broad recommendations and suggestions that can then be adapted and adopted in each jurisdiction. This guidance should focus on: developing and implementing a social model of disability via a structured and principled process; measures that may prevent and proactively address disability; collaboratively identifying and implementing appropriate reasonable accommodations; and ensuring individual independence is maintained and nurtured, even in the face of judicial infirmity.

Guidance should also address the different considerations that might apply to situations of temporary and permanent incapacity. Temporary incapacity might be more easily remedied by short-term accommodations, such as a time away from sitting duties, or additional support for a certain period of time. Where, however, incapacity is likely to be ongoing, more concern will need to be given to the sustainability - both individual and institutional - of different accommodations. Again, these considerations will be context and jurisdiction specific, and will likely reflect the size of the court and its workload, the ability (or not) to recruit temporary judges to help manage the courts' demands, and available court resources. Further, guidance should acknowledge that sometimes the duration or impact of incapacity will be uncertain or subject to change, and should therefore allow for and encourage the regular review and revisiting of arrangements that are put in place.

While this guidance can be developed by the Judicial Conference of Australia or the Council of Chief Justices without statutory footing, its implementation would be enabled by a more sympathetic statutory framework. For example, a statutory provision could be adopted that explicitly empowers the head of jurisdiction, upon becoming aware of any disability, infirmity or incapacity, or potential disability, infirmity or incapacity, to "make any modifications or accommodations to the court or judicial role as they see fit to help manage or minimise the impact of the impairment'. Further, the head of jurisdiction could be explicitly empowered to adopt 'a holistic programme or policy for supporting, assisting and managing cases of impairment or potential impairment'. These suggested phrases may seem a little ungainly when contrasted with the economical expression of the responsibility that falls to a head of jurisdiction to 'deal with' a situation of incapacity - but what they lack in brevity, they compensate for by pointing to a better and fairer outcome for the individual concerned. 
A process of this nature is likely to support and promote equality and diversity in the judiciary. Conversely, established methods for managing incapacity - the 'tap on the shoulder', informal processes, and relying on mandatory retirement to remove the oldest judges - risk embedding discrimination in court practices. ${ }^{150}$ While some conditions may be more common in older age, incapacity is certainly not confined to older judges. Further, a holistic and structured process of this nature is unlikely to amount to 'detriment' for or unfavourable treatment of individual judges - rather, it is a positive development in helping judges to navigate instances of infirmity. Thus, moving towards this means of managing incapacity is likely to advance equality and diversity in the judiciary more generally, and is unlikely to fall afoul of other areas of discrimination law.

\section{CONCLUSION}

It is high time that we moved past a professional reticence to acknowledge and discuss judicial incapacity, especially in relation to the workload and resourcing of courts as exacerbating factors. ${ }^{151}$ There are strong social and constitutional reasons for candid and direct engagement with these issues. Social considerations include the great strides in recent decades towards the better protection of the rights of persons with disabilities to equitable treatment, accompanied by a deepening awareness and understanding of mental health issues and the impact of professional environments upon individual wellbeing. What may have been regarded as 'incapacity' in an earlier era may be rather less likely to be so perceived today. Breaking down the traditional equivalency between impairment and incapacity is an important first step. But this is also part of a larger need to recognise incapacity on its own terms, distinct from misbehaviour, and not just as simply another ground for judicial removal. That distinctiveness should be acknowledged in the identification of and responses made to incapacity - and the processes that attend each. As emphasised throughout this paper, a move to defining incapacity by reference not simply to the individual's physical or mental condition but also the obligations upon the court to attempt to accommodate that condition reframes the topic and brings the court's ethical responsibilities toward the individual judge into sharper focus. More broadly still, a direct embrace of a social model of disability recognises the responsibility of governments to adequately resource the courts, such that they can do their work in a way that meets the needs of the community while being also sustainable in terms of the impact and load on the judicial workforce. That is undoubtedly a larger dimension to the discussion, only occasionally touched on in this article, but critical to a full appreciation of the context in which the individual judge is operating.

The constitutional significance of this topic is plain. Approaches to perceived incapacity that are essentially informal and unstructured threaten judicial independence, as they increase the likelihood that an individual may be pressured - either directly or indirectly through the absence of reasonable adjustments that would help them to continue in office - to leave the bench. The fact that this may be done with the well-meaning collegiality that was intimated by

150 See especially Blackham, ‘Reconceiving Judicial Office through a Labour Law Lens’ (n 16); Blackham, 'Judges and Retirement Ages' (n 17).

151 That to do so remains very rare is evidenced by the publicity attracted by a speech of New South Wales District Court Judge Robyn Tupman in which she expressed concerns about the effect of workload on her colleagues and a 'fear' for their wellbeing, making reference to the suicide of two Victorian Magistrates over the preceding year: Angus Thompson, "II Fear for My Colleagues": Judge Warns NSW Judiciary Workload Could Have Tragic Consequences', Sydney Morning Herald (online, 5 October 2018) $<$ https:/www.smh.com.au/national/nsw/i-fear-for-my-colleagues-judge-warns-nsw-judiciary-workloadcould-have-tragic-consequences-20181004-p507tv.html>. 
Justice Thomas when he discussed such practices is beside the point. The adoption of clearer guiding principles around the obligation of the court to 'deal with any impairment', to the degree this does not conflict with the inherent requirements of judicial office, would be a vast improvement to informally handling cases where judicial health has the potential to impact upon performance. In bringing the judicial sphere into better alignment with the legal standards that nowadays underpin management and support of disability in the workplace, we would not only be being much fairer to the individuals whose health has, whether permanently or temporarily, diminished in some way; we would also be showing a keener respect for judges' security of tenure and thus the principle of judicial independence. 